\title{
Arcicella aurantiaca sp. nov., isolated from stream water
}

\author{
Shih-Yi Sheu, ${ }^{1}$ Cho-Song Yang, ${ }^{2}$ Ming-Hui Chen, ${ }^{2}$ A. B. Arun, ${ }^{3}$ \\ Chiu-Chung Young ${ }^{4}$ and Wen-Ming Chen ${ }^{2}$
}

Correspondence Wen-Ming Chen p62365@ms28.hinet.net

\author{
${ }^{1}$ Department of Marine Biotechnology, National Kaohsiung Marine University, No. 142, \\ Hai-Chuan Rd, Nan-Tzu, Kaohsiung City 811, Taiwan, ROC \\ ${ }^{2}$ Laboratory of Microbiology, Department of Seafood Science, National Kaohsiung Marine \\ University, No. 142, Hai-Chuan Rd, Nan-Tzu, Kaohsiung City 811, Taiwan, ROC \\ ${ }^{3}$ Yenepoya Research Center, Yenepoya University, University Rd, Deralakatee, Mangalore, \\ Karnataka, India \\ ${ }^{4}$ Department of Soil Environmental Science, College of Agriculture and Natural Resources, \\ National Chung Hsing University, Taichung, Taiwan, ROC
}

\begin{abstract}
A bacterial strain designated TNR-18 ${ }^{\top}$ was isolated from stream water in southern Taiwan and characterized using a polyphasic taxonomic approach. Cells of strain TNR-18 ${ }^{\top}$ were Gram-stainnegative, strictly aerobic, non-motile and vibrioid, and the strain formed orange colonies. Growth occurred at $10-30{ }^{\circ} \mathrm{C}$, with $0-0.2 \% \mathrm{NaCl}$ and at $\mathrm{pH}$ 6.0-10.0. Phylogenetic analyses based on $16 \mathrm{~S}$ rRNA gene sequences showed that strain TNR-18 ${ }^{\top}$ belonged to the genus Arcicella; its closest neighbours were Arcicella rosea $\mathrm{TW}^{\top}$ and Arcicella aquatica NO-502 ${ }^{\top}$, with respective sequence similarities of 97.9 and $97.8 \%$. Predominant cellular fatty acids $(>10 \%)$ were summed feature $3\left(\mathrm{C}_{16: 1} \omega 7 c / \mathrm{C}_{16: 1} \omega 6 c ; 37.7 \%\right), \mathrm{C}_{16: 1} \omega 5 c(13.0 \%)$ and iso- $\mathrm{C}_{15: 0}(11.1 \%)$. The major respiratory quinone was $\mathrm{MK}-7$. The polar lipid profile contained phosphatidylethanolamine, phosphatidylglycerol, diphosphatidylglycerol and several uncharacterized polar lipids. The DNA $\mathrm{G}+\mathrm{C}$ content was $39.9 \mathrm{~mol} \%$. On the basis of the phylogenetic and phenotypic data, strain TNR-18 ${ }^{\top}$ should be classified as representing a novel species, for which the name Arcicella aurantiaca sp. nov. is proposed. The type strain is TNR-18 ${ }^{\top}\left(=\right.$ LMG $25207^{\top}=$ BCRC $\left.17969^{\top}\right)$.
\end{abstract}

The genus Arcicella, first proposed by Nikitin et al. (2004), belongs to the family Cytophagaceae of the order Cytophagales, class 'Cytophagia', phylum Bacteroidetes (Ludwig et al., 2008). At the time of writing, the genus contains only two species with validly published names, the type species Arcicella aquatica, isolated from a neuston film on a freshwater lake (Nikitin et al., 2004), and Arcicella rosea, from tap water (Kämpfer et al., 2009). The present study was carried out to clarify the taxonomic position of the Arcicella-like bacterial strain TNR $-18^{\mathrm{T}}$ by a polyphasic taxonomic approach.

Stream water (approx. $200 \mathrm{ml}$ ) was collected in a sterile bag from Maolin township (GPS location $22^{\circ} 54^{\prime} 12.5^{\prime \prime} \mathrm{N}$ $120^{\circ} 40^{\prime}$ 59.9' E) in Kaohsiung Prefecture, southern Taiwan, stored at $4{ }^{\circ} \mathrm{C}$ and transported to the laboratory within $2 \mathrm{~h}$. The water sample was spread-plated on R2A agar (BD Difco) following the standard dilution plating

The GenBank/EMBL/DDBJ accession number for the 16S rRNA gene sequence of strain TNR-18 ${ }^{\top}$ is FJ593908.

Results of 2D TLC of polar lipids of strain TNR-18 ${ }^{\top}$ are available as supplementary material with the online version of this paper. method. After incubation of the plates at $25{ }^{\circ} \mathrm{C}$ for 5 days, strain TNR-18 ${ }^{\mathrm{T}}$ was purified as a single colony. The strain was preserved at $-80{ }^{\circ} \mathrm{C}$ as a $20 \%(\mathrm{v} / \mathrm{v})$ glycerol suspension in R2A broth or by lyophilization with $20 \%(\mathrm{w} / \mathrm{v})$ skimmed milk. A. aquatica LMG $21963^{\mathrm{T}}$ and A. rosea CCUG $55942^{\mathrm{T}}$ were obtained from the Belgian Coordinated Collections of Microorganisms and the Culture Collection of the University of Göteborg, respectively, for detailed comparisons.

Bacterial cells were observed by phase-contrast microscopy (DM 2000; Leica) in the lag, exponential and stationary phases of growth to ascertain their morphology. Flagellar and gliding motility were tested using the hanging drop method. Spot Test flagella stain (BD Difco) was used to stain any flagella that might be present. The Gram stain set (BD Difco) kit and the Ryu non-staining $\mathrm{KOH}$ method (Powers, 1995) were used to test Gram-staining behaviour. Colony morphology was examined on R2A agar using a stereoscopic microscope (SMZ 800; Nikon). The presence of flexirubin-type pigments and carotenoids was investigated as described by Reichenbach (1992), Bernardet et al. (2002) and Schmidt et al. (1994). 
The $\mathrm{pH}$ range for growth was determined by measuring the $\mathrm{OD}_{600}$ of R2A broth cultures (BD Difco). The medium was adjusted to $\mathrm{pH} 4.0-10.0$ (at intervals of $0.5 \mathrm{pH}$ units) using appropriate biological buffers (Chung et al., 1995). To investigate the tolerance of $\mathrm{NaCl}, \mathrm{R} 2 \mathrm{~A}$ broth was prepared according to the formula of the BD Difco medium with the $\mathrm{NaCl}$ concentration adjusted to $0-1.0 \%(\mathrm{w} / \mathrm{v})$ (at intervals of $0.1 \%)$. The temperature range for growth was determined in R2A broth at 4 and $10-45{ }^{\circ} \mathrm{C}$ (at intervals of $5{ }^{\circ} \mathrm{C}$ ). Growth under anaerobic conditions was determined after incubating strain TNR-1 $18^{\mathrm{T}}$ in the Oxoid AnaeroGen system.

Strain TNR- $18^{\mathrm{T}}$ was examined for a broad range of phenotypic properties. Activities of catalase, oxidase and lipase (corn oil) and hydrolysis of starch, casein and Tweens 20, 40, 60 and 80 were determined according to standard methods (Gerhardt et al., 1994). Additional biochemical tests were performed using the API ZYM and API 20NE kits (bioMérieux) and carbon source utilization was evaluated using the Biolog GN2 microplate. Phenotypic tests using commercial kits were performed according to the manufacturers' recommendations.

Sensitivity of strain TNR- $18^{\mathrm{T}}$ to antibiotics was tested by the disc diffusion method after spreading cell suspensions (0.5 McFarland) on R2A agar (BD Difco) plates. The discs (Oxoid) contained the following antibiotics: ampicillin $(10 \mu \mathrm{g})$, chloramphenicol $(30 \mu \mathrm{g})$, gentamicin $(10 \mu \mathrm{g})$, kanamycin $(30 \mu \mathrm{g})$, nalidixic acid $(30 \mu \mathrm{g})$, novobiocin $(30 \mu \mathrm{g})$, penicillin $\mathrm{G}(10 \mu \mathrm{g})$, rifampicin $(5 \mu \mathrm{g})$, streptomycin $(10 \mu \mathrm{g})$, sulfamethoxazole plus trimethoprim $(23.75 / 1.25 \mu \mathrm{g})$ and tetracycline $(30 \mu \mathrm{g})$. The effect of antibiotics on cell growth was assessed after 3 days of incubation at $25{ }^{\circ} \mathrm{C}$. The strain was considered susceptible when the diameter of the inhibition zone was $>13 \mathrm{~mm}$, intermediate at $10-12 \mathrm{~mm}$ and resistant at $<10 \mathrm{~mm}$. Detailed results from the phenotypic and biochemical analyses of strain TNR-18 $8^{\mathrm{T}}$ are provided in Table 1 and the species description. Phenotypic characteristics that serve to differentiate strain TNR-18 ${ }^{\mathrm{T}}$ from the type strains of the genus Arcicella are presented in Table 1.

The 16S rRNA gene sequence was analysed as described previously by Chen et al. (2001). Analysis of the sequence was performed by using the software BioEdit (Hall, 1999) and MEGA version 3.1 (Kumar et al., 2004) after multiple alignment of the data by CLUSTAL_X (Thompson et al., 1997). Distances (corrected according to Kimura's twoparameter model; Kimura, 1983) were calculated and clustering was performed with the neighbour-joining method (Saitou \& Nei, 1987). Maximum-likelihood (Felsenstein, 1981) and maximum-parsimony (Kluge \& Farris, 1969) trees were generated by using the treeing algorithms contained in the PHYLIP software package (Felsenstein, 1993). In each case, bootstrap values were calculated based on 1000 replications. An almost-complete $16 \mathrm{~S}$ rRNA gene sequence (1411 bp) of strain TNR-18 $8^{\mathrm{T}}$ was compared against $16 \mathrm{~S}$ rRNA gene sequences available from
Table 1. Differential characteristics of type strains of Arcicella species

Strains: 1 , A. aurantiaca sp. nov. TNR $-18^{\mathrm{T}} ; 2$, A. aquatica LMG $21963^{\mathrm{T}}$; 3, A. rosea CCUG $55942^{\mathrm{T}}$. Data were acquired in this study. + , Positive; -, negative; w, weakly positive. All strains stain Gramnegative and are positive for C8 esterase lipase, leucine arylamidase, trypsin, naphthol-AS-BI-phosphohydrolase, $\alpha$-glucosidase and $\mathrm{N}$ acetyl- $\beta$-glucosaminidase activities and negative for indole production, glucose fermentation, arginine dihydrolase, urease, C14 lipase, $\beta$-glucuronidase, $\alpha$-mannosidase and lipase (corn oil) activities and hydrolysis of Tweens 20, 40, 60 and 80 .

\begin{tabular}{|c|c|c|c|}
\hline Characteristic & 1 & 2 & 3 \\
\hline Colony pigmentation ${ }^{*}$ & $\mathrm{O}$ & LO & PP \\
\hline Mucus formation & - & + & + \\
\hline $\mathrm{NaCl}$ range for growth (\%) & $0-0.2$ & $0-0.5$ & $0-0.7$ \\
\hline Catalase & + & - & + \\
\hline Oxidase & $\mathrm{w}$ & $\mathrm{W}$ & - \\
\hline \multicolumn{4}{|l|}{ Hydrolysis of: } \\
\hline Casein & + & - & - \\
\hline Aesculin & + & + & - \\
\hline \multicolumn{4}{|l|}{ Oxidation of (GN2): } \\
\hline L-Fucose & + & - & - \\
\hline Methyl $\beta$-D-glucoside & + & $\mathrm{w}$ & + \\
\hline Raffinose & + & - & - \\
\hline Pyruvic acid methyl ester & + & - & + \\
\hline Acetic acid & + & - & $\mathrm{W}$ \\
\hline D-Galactonic acid lactone & + & - & - \\
\hline D-Glucosaminic acid & + & - & $\mathrm{w}$ \\
\hline$\alpha$-Ketobutyric acid & + & - & - \\
\hline$\alpha$-Ketoglutaric acid & + & - & - \\
\hline$\alpha$-Ketovaleric acid & + & - & - \\
\hline DL-Lactic acid & + & - & + \\
\hline Quinic acid & + & - & - \\
\hline L-Alaninamide & + & - & + \\
\hline L-Alanine & + & - & + \\
\hline L-Alanyl glycine & + & - & + \\
\hline L-Aspartic acid & + & - & + \\
\hline L-Glutamic acid & + & - & + \\
\hline Glycyl L-aspartic acid & + & - & $\mathrm{w}$ \\
\hline Glycyl L-glutamic acid & + & - & $\mathrm{w}$ \\
\hline L-Serine & + & - & + \\
\hline Inosine & + & - & - \\
\hline Uridine & + & - & - \\
\hline$\alpha$-D-Glucose 1-phosphate & + & - & + \\
\hline D-Glucose 6-phosphate & + & - & - \\
\hline \multicolumn{4}{|l|}{ Enzyme activity (API ZYM) } \\
\hline Alkaline phosphatase & + & + & - \\
\hline C4 esterase & - & + & - \\
\hline Acid phosphatase & + & + & - \\
\hline
\end{tabular}

${ }^{\star}$ LO, Light orange; O, orange; PP, pale pink.

the EzTaxon server (Chun et al., 2007), the Ribosomal Database Project (Maidak et al., 2001) and the GenBank database (http://www.ncbi.nlm.nih.gov/). 16S rRNA gene sequence analysis indicated that strain TNR- $18^{\mathrm{T}}$ belonged 
to the family Cytophagaceae (order Cytophagales, class 'Cytophagia', phylum Bacteroidetes). Strain TNR-18 formed a distinct subline within the genus Arcicella in the neighbour-joining tree (Fig. 1). The overall topologies of the phylogenetic trees retrieved by the maximumlikelihood and maximum-parsimony methods were similar. Sequence similarity calculations (over $1400 \mathrm{bp}$ ) indicated that strain TNR- $18^{\mathrm{T}}$ was closely related to $A$. rosea TW5 $^{\mathrm{T}}$ (97.9\% 16S rRNA gene sequence similarity) and $A$. aquatica $\mathrm{NO}-502^{\mathrm{T}}(97.8 \%)$. Lower sequence similarities $(<93.1 \%)$ were found with representative members of all other genera listed in Fig. 1.

Whole genome DNA-DNA hybridization experiments were carried out with photobiotin-labelled probes as described by Ezaki et al. (1989). The degree of hybridization was calculated as the mean of triplicate experiments. Separate species status of strain TNR-18 $8^{\mathrm{T}}$ was confirmed by the hybridization values obtained with $A$. aquatica $\mathrm{LMG}$ $21963^{\mathrm{T}}$ and A. rosea CCUG $55942^{\mathrm{T}}(59.5 \pm 3.1$ and $23.1 \pm$ $2.4 \%$, respectively). The DNA-DNA relatedness between strain TNR $-18^{\mathrm{T}}$ and its closest phylogenetic neighbours was well below the $70 \%$ cut-off point recommended for the assignment of strains to the same genomic species (Wayne et al., 1987). Based on the above data, strain TNR-18 ${ }^{\mathrm{T}}$ warrants separate species status in the genus Arcicella.

Fatty acid methyl esters were prepared, separated and identified according to the instructions of the Microbial Identification System (Microbial ID; Sasser, 1990). The fatty acid profiles of strain TNR-18 ${ }^{\mathrm{T}}$, A. aquatica LMG $21963^{\mathrm{T}}$ and A. rosea CCUG $55942^{\mathrm{T}}$ were determined using cells grown on R2A agar at $25{ }^{\circ} \mathrm{C}$ for 3 days. The fatty acid profile of strain TNR-18 ${ }^{\mathrm{T}}$ was similar to those of the other two Arcicella type strains, although there were differences in the proportions of some components (Table 2). Cellular fatty acids present in strain TNR-18 ${ }^{\mathrm{T}}$ at $\geqslant 1 \%$ included summed feature $3\left(\mathrm{C}_{16: 1} \omega 7 c\right.$ and/or $\left.\mathrm{C}_{16: 1} \omega 6 c\right), \mathrm{C}_{16: 1} \omega 5 c$, iso- $\mathrm{C}_{15: 0}$, iso- $\mathrm{C}_{15: 0} 3-\mathrm{OH}, \mathrm{C}_{16: 0}, \mathrm{C}_{16: 0} 3-\mathrm{OH}$, iso- $\mathrm{C}_{17: 0} 3-$ $\mathrm{OH}, \mathrm{C}_{14: 0}$, anteiso- $\mathrm{C}_{15: 0}, \mathrm{C}_{15: 1} \omega 6 c$, iso- $\mathrm{C}_{17: 1} \omega 9 c$ and $\mathrm{C}_{18: 0}$. Isoprenoid quinones were extracted and purified according to the method of Collins (1985) and analysed by HPLC; the major respiratory quinone of strain TNR- $18^{\mathrm{T}}$ was MK-7. The DNA G + C content of strain TNR-18 ${ }^{\mathrm{T}}$, determined by HPLC according to Mesbah et al. (1989), was $39.9 \pm 1.0 \mathrm{~mol} \%$.

Polar lipids were extracted and analysed by two-dimensional TLC according to Lechevalier et al. (1977). Strain TNR- $18^{\mathrm{T}}$ exhibited a complex polar lipid profile consisting of phosphatidylethanolamine, phosphatidylglycerol, diphosphatidylglycerol and several uncharacterized polar lipids (see Supplementary Fig. S1, available in IJSEM Online). Strain TNR-18 ${ }^{\mathrm{T}}$ exhibited a polar lipid profile very similar to that of its closest relative, A. rosea TW5 ${ }^{\mathrm{T}}$ (Kämpfer et al., 2009), in which the predominant compounds were also phosphatidylethanolamine and an unknown aminophospholipid.

On the basis of 16S rRNA gene sequence similarity, strain TNR- $18^{\mathrm{T}}$ occupies a distinct position within the genus Arcicella. This result was supported by the unique combination of chemotaxonomic characteristics and biochemical traits of the strain (Table 1). Based on 16S rRNA gene sequence similarity, DNA-DNA relatedness, fatty acid profile, major respiratory quinone, DNA G $+C$ content and phenotypic properties, it is evident that strain TNR$18^{\mathrm{T}}$ should be classified as the type strain of a novel species in the genus Arcicella, for which the name Arcicella aurantiaca sp. nov. is proposed.

\section{Description of Arcicella aurantiaca sp. nov.}

Arcicella aurantiaca (au.ran.ti.a'ca. N.L. fem. adj. aurantiaca orange-coloured).

Cells are Gram-stain-negative, strictly aerobic, vibrioid and non-motile. After $72 \mathrm{~h}$ of incubation on R2A agar at $25{ }^{\circ} \mathrm{C}$, mean cell dimensions are $0.5-0.6 \mu \mathrm{m}$ diameter and $1.0-$ $3.0 \mu \mathrm{m}$ length. Colonies on R2A agar are orange, nonmucous, circular, smooth and convex with entire edges. Colonies are approximately $1.0-1.5 \mathrm{~mm}$ in diameter on R2A agar after $72 \mathrm{~h}$ of incubation at $25{ }^{\circ} \mathrm{C}$. Growth occurs at $10-30{ }^{\circ} \mathrm{C}$, with $0-0.2 \% \mathrm{NaCl}$ and at $\mathrm{pH} 6.0-10.0$. Optimum growth occurs at $25{ }^{\circ} \mathrm{C}$, in the absence of $\mathrm{NaCl}$ and at $\mathrm{pH}$ 7.0. Carotenoid/flexirubin pigments are absent. Positive for catalase and oxidase activities and hydrolysis of

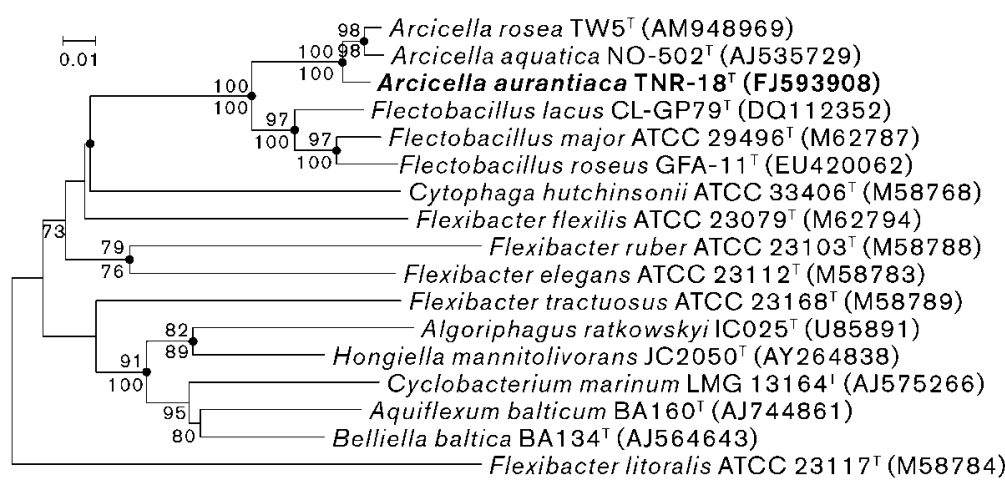

Fig. 1. Neighbour-joining phylogenetic tree based on 16S rRNA gene sequences showing the position of Arcicella aurantiaca sp. nov. TNR-18 ${ }^{\top}$ and related taxa in the class 'Cytophagia'. Numbers at nodes are bootstrap percentages $(>70 \%)$ based on the neighbour-joining (above nodes) and maximumparsimony (below nodes) tree-making algorithms. Filled circles indicate branches of the tree that were also recovered using the maximum-likelihood and maximum-parsimony algorithms. Flexibacter litoralis ATCC $23117^{\top}$ was used as an outgroup. Bar, 0.01 substitutions per nucleotide position. 
Table 2. Cellular fatty acid compositions of the type strains of Arcicella species

Strains: 1 , A. aurantiaca sp. nov. TNR $-18^{\mathrm{T}} ; 2$, A. aquatica LMG $21963^{\mathrm{T}}$; 3, A. rosea CCUG $55942^{\mathrm{T}}$. Data were acquired in this study. Values are percentages of total fatty acids. Fatty acids that made up $<1 \%$ of the total in all strains are not shown;,$-<1 \%$. For unsaturated fatty acids, the position of the double bond is located by counting from the methyl $(\omega)$ end of the carbon chain; cis isomers are indicated by the suffix $c$.

\begin{tabular}{|c|c|c|c|}
\hline Fatty acid & 1 & 2 & 3 \\
\hline $\mathrm{C}_{10: 0}$ & - & 1.5 & - \\
\hline iso- $\mathrm{C}_{10: 0}$ & - & 1.1 & - \\
\hline $\mathrm{C}_{14: 0}$ & 1.5 & 1.9 & 1.9 \\
\hline anteiso- $\mathrm{C}_{15: 0}$ & 1.4 & 1.0 & 1.1 \\
\hline iso- $\mathrm{C}_{15: 0}$ & 11.1 & 7.8 & 11.1 \\
\hline iso- $\mathrm{C}_{15: 0} 3-\mathrm{OH}$ & 8.1 & 5.4 & 4.7 \\
\hline $\mathrm{C}_{15: 1} \omega 6 c$ & 1.4 & - & - \\
\hline $\mathrm{C}_{16: 0}$ & 5.0 & 8.0 & 6.9 \\
\hline $\mathrm{C}_{16: 0} 3-\mathrm{OH}$ & 4.6 & 5.0 & 3.8 \\
\hline $\mathrm{C}_{16: 1} \omega 5 c$ & 13.0 & 22.2 & 21.0 \\
\hline iso- $\mathrm{C}_{17: 0} 3-\mathrm{OH}$ & 3.0 & 2.0 & 3.4 \\
\hline iso- $\mathrm{C}_{17: 1} \omega 9 c$ & 1.3 & - & - \\
\hline $\mathrm{C}_{18: 0}$ & 1.0 & - & 1.1 \\
\hline Summed feature $3^{*}$ & 37.7 & 37.6 & 36.0 \\
\hline
\end{tabular}

${ }^{\star}$ Summed feature 3 are groups of two or three fatty acids that cannot be separated by GLC using the MIDI system. Summed feature 3 contains $\mathrm{C}_{16: 1} \omega 7 c$ and/or $\mathrm{C}_{16: 1} \omega 6 c$.

casein and starch. Negative for lipase activity and hydrolysis of Tweens 20, 40, 60 and 80. In API 20NE tests, positive for nitrate reduction, aesculin hydrolysis, gelatin hydrolysis and $\beta$-galactosidase activity and negative for indole production, D-glucose fermentation and arginine dihydrolase and urease activities. In API ZYM tests, alkaline phosphatase, C8 esterase lipase, leucine arylamidase, trypsin, acid phosphatase, naphthol-AS-BI-phosphohydrolase, $\beta$-galactosidase, $\alpha$-glucosidase and $N$-acetyl- $\beta$ glucosaminidase activities are present and C4 esterase, C14 lipase, valine arylamidase, cystine arylamidase, $\alpha$-chymotrypsin, $\alpha$-galactosidase, $\beta$-glucuronidase, $\beta$-glucosidase, $\alpha$-mannosidase and $\alpha$-fucosidase activities are absent. The following compounds in the Biolog GN2 microplate are utilized as sole carbon sources: $\alpha$-cyclodextrin, dextrin, glycogen, $N$-acetyl-D-galactosamine, $N$-acetyl-D-glucosamine, cellobiose, D-fructose, L-fucose, D-galactose, gentiobiose, $\alpha$-D-glucose, lactose, lactulose, maltose, D-mannose, melibiose, methyl $\beta$-D-glucoside, D-psicose, raffinose, L-rhamnose, D-sorbitol, sucrose, trehalose, turanose, pyruvic acid methyl ester, succinic acid monomethyl ester, acetic acid, D-galactonic acid lactone, D-galacturonic acid, D-gluconic acid, D-glucosaminic acid, D-glucuronic acid, $\alpha$ ketobutyric acid, $\alpha$-ketoglutaric acid, $\alpha$-ketovaleric acid, DL-lactic acid, propionic acid, quinic acid, succinic acid, Lalaninamide, L-alanine, L-alanyl glycine, L-aspartic acid,
L-glutamic acid, glycyl L-aspartic acid, glycyl L-glutamic acid, hydroxy-L-proline, L-serine, inosine, uridine, 2,3butanediol, $\alpha$-D-glucose 1-phosphate and D-glucose 6phosphate. Other substrates in the GN2 microplate are not utilized. Sensitive to tetracycline, sulfamethoxazole, rifampicin, novobiocin, streptomycin, chloramphenicol, nalidixic acid, penicillin $\mathrm{G}$ and ampicillin and resistant to gentamicin and kanamycin. The predominant cellular fatty acids $(>10 \%)$ are summed feature $3\left(\mathrm{C}_{16: 1} \omega 7 c / \mathrm{C}_{16: 1} \omega 6 c\right)$, $\mathrm{C}_{16: 1} \omega 5 c$ and iso- $\mathrm{C}_{15: 0}$. The major respiratory quinone is MK-7. The polar lipid profile consists of a mixture of phosphatidylethanolamine, phosphatidylglycerol, diphosphatidylglycerol and several uncharacterized polar lipids; the predominant polar lipids are phosphatidylethanolamine and an unknown aminophospholipid. The DNA $\mathrm{G}+\mathrm{C}$ content of the type strain is $39.9 \mathrm{~mol} \%$.

The type strain is TNR- $18^{\mathrm{T}}\left(=\mathrm{LMG} 25207^{\mathrm{T}}=\mathrm{BCRC}\right.$ $17969^{\mathrm{T}}$ ), isolated from stream water in Kaohsiung Prefecture, southern Taiwan.

\section{References}

Bernardet, J.-F., Nakagawa, Y. \& Holmes, B. (2002). Proposed minimal standards for describing new taxa of the family Flavobacteriaceae, and emended description of the family. Int J Syst Evol Microbiol 52, 1049-1070.

Chen, W. M., Laevens, S., Lee, T. M., Coenye, T., De Vos, P., Mergeay, M. \& Vandamme, P. (2001). Ralstonia taiwanensis sp. nov., isolated from root nodules of Mimosa species and sputum of a cystic fibrosis patient. Int J Syst Evol Microbiol 51, 1729-1735.

Chun, J., Lee, J.-H., Jung, Y., Kim, M., Kim, S., Kim, B. K. \& Lim, Y. W. (2007). EzTaxon: a web-based tool for the identification of prokaryotes based on $16 \mathrm{~S}$ ribosomal RNA gene sequences. Int J Syst Evol Microbiol 57, 2259-2261.

Chung, Y. C., Kobayashi, T., Kanai, H., Akiba, T. \& Kudo, T. (1995). Purification and properties of extracellular amylase from the hyperthermophilic archeon Thermococcus profundus DT5432. Appl Environ Microbiol 61, 1502-1506.

Collins, M. D. (1985). Isoprenoid quinone analysis in classification and identification. In Chemical Methods in Bacterial Systematics, pp. 267-287. Edited by M. Goodfellow \& D. E. Minnikin. London: Academic Press.

Ezaki, T., Hashimoto, Y. \& Yabuuchi, E. (1989). Fluorometric deoxyribonucleic acid-deoxyribonucleic acid hybridization in microdilution wells as an alternative to membrane filter hybridization in which radioisotopes are used to determine genetic relatedness among bacterial strains. Int J Syst Bacteriol 39, 224229.

Felsenstein, J. (1981). Evolutionary trees from DNA sequences: a maximum likelihood approach. J Mol Evol 17, 368-376.

Felsenstein, J. (1993). PHYLIP (phylogeny inference package), version 3.5c. Distributed by the author. Department of Genome Sciences, University of Washington, Seattle, USA.

Gerhardt, P., Murray, R. G. E., Wood, W. A. \& Krieg, N. R. (editors) (1994). Methods for General and Molecular Bacteriology. Washington, DC: American Society for Microbiology.

Hall, T. A. (1999). BioEdit: a user-friendly biological sequence alignment editor and analysis program for Windows 95/98/NT. Nucleic Acids Symp Ser 41, 95-98. 
Kämpfer, P., Lodders, N. \& Busse, H.-J. (2009). Arcicella rosea sp. nov., isolated from tap water. Int J Syst Evol Microbiol 59, 341-344.

Kimura, M. (1983). The Neutral Theory of Molecular Evolution. Cambridge: Cambridge University Press.

Kluge, A. G. \& Farris, J. S. (1969). Quantitative phyletics and the evolution of anurans. Syst Zool 18, 1-32.

Kumar, S., Tamura, K. \& Nei, M. (2004). MEGA3: integrated software for molecular evolutionary genetics analysis and sequence alignment. Brief Bioinform 5, 150-163.

Lechevalier, M. P., De Bièvre, C. \& Lechevalier, H. A. (1977) Chemotaxonomy of aerobic actinomycetes: phospholipid composition. Biochem Syst Ecol 5, 249-260.

Ludwig, W., Euzéby, J. \& Whitman, W. B. (2008). Draft taxonomic outline of the Bacteroidetes, Planctomycetes, Chlamydiae, Spirochaetes, Fibrobacteres, Fusobacteria, Acidobacteria, Verrucomicrobia, Dictyoglomi, and Gemmatimonadetes. http://www.bergeys.org/outlines/Bergeys_Vol_ 4_Outline.pdf

Maidak, B. L., Cole, J. R., Lilburn, T. G., Parker, C. T., Jr, Saxman, P. R., Farris, R. J., Garrity, G. M., Olsen, G. J., Schmidt, T. M. \& Tiedje, J. M. (2001). The RDP-II (Ribosomal Database Project). Nucleic Acids Res 29, 173-174.

Mesbah, M., Premachandran, U. \& Whitman, W. B. (1989). Precise measurement of the $\mathrm{G}+\mathrm{C}$ content of deoxyribonucleic acid by highperformance liquid chromatography. Int J Syst Bacteriol 39, 159-167.

Nikitin, D. I., Strömpl, C., Oranskaya, M. S. \& Abraham, W.-R. (2004). Phylogeny of the ring-forming bacterium Arcicella aquatica gen. nov., sp. nov. (ex Nikitin et al. 1994), from a freshwater neuston biofilm. Int J Syst Evol Microbiol 54, 681-684.

Powers, E. M. (1995). Efficacy of the Ryu nonstaining KOH technique for rapidly determining gram reactions of food-borne and waterborne bacteria and yeasts. Appl Environ Microbiol 61, 3756-3758.

Reichenbach, H. (1992). The order Cytophagales. In The Prokaryotes, 2nd edn, vol. 4, pp. 3631-3675. Edited by A. Balows, H. G. Trüper, M. Dworkin, W. Harder \& K. H. Schleifer. New York: Springer.

Saitou, N. \& Nei, M. (1987). The neighbor-joining method: a new method for reconstructing phylogenetic trees. Mol Biol Evol 4, 406425.

Sasser, M. (1990). Identification of bacteria by gas chromatography of cellular fatty acids, MIDI Technical Note 101. Newark, DE: MIDI Inc.

Schmidt, K., Connor, A. \& Britton, G. (1994). Analysis of pigments: carotenoids and related polyenes. In Chemical Methods in Prokaryotic Systematics, pp. 403-461. Edited by M. Goodfellow \& A. G. O’Donnell. Chichester: Wiley.

Thompson, J. D., Gibson, T. J., Plewniak, F., Jeanmougin, F. \& Higgins, D. G. (1997). The CLUSTAL_X windows interface: flexible strategies for multiple sequence alignment aided by quality analysis tools. Nucleic Acids Res 25, 4876-4882.

Wayne, L. G., Brenner, D. J., Colwell, R. R., Grimont, P. A. D., Kandler, O., Krichevsky, M. I., Moore, L. H., Moore, W. E. C., Murray, R. G. E. \& other authors (1987). International Committee on Systematic Bacteriology. Report of the ad hoc committee on reconciliation of approaches to bacterial systematics. Int J Syst Bacteriol 37, 463-464. 